\title{
Rumah Tinggal Tan Tjwan Bie di Surabaya: Studi Langgam Arsitekturnya
}

\author{
Joko Triwinarto Santoso \\ Jurusan Arsitektur, Fakultas Teknik, Universitas Brawijaya \\ jokotris@yahoo.com,jokotris@ub.ac.id
}

\begin{abstract}
ABSTRAK
Di dalam stratifikasi sosial yang dibuat oleh pemerintah kolonial Hindia Belanda, komunitas Tionghoa menduduki peringkat kedua setelah bangsa Eropa. Mereka menetap tersebar di berbagai kota, salah satunya di Kota Surabaya. Di kota ini mereka juga menempati tempat kedua setelah pribumi dalam hal jumlah populasi. Tan Tjwan Bie, salah satu anggota komunitas tersebut, dikenal sebagai pendiri Pabrik Gula Kebon Agung di Malang. Dengan kemampuan keuangannya, ia mampu menugaskan arsitek Cosman Citroen, salah satu arsitek terkenal di Hindia Belanda, dan Gerard Pieter Adolfs, pelukis bereputasi internasional, untuk merancang rumahnya, serta kontraktor terkemuka Nedam untuk mengerjakan pembangunan rumah tinggalnya di kota ini hingga selesai pada tahun 1928. Pada masa itu arsitektur modern sedang berkembang pesat. Sebagai karya kolaborasi berbagai pihak yang menonjol dan berbeda latar belakangnya, bangunan ini layak untuk diteliti langgam arsitekturalnya. Artikel ini bertujuan untuk mengidentifikasi sejauh mana pengaruh arsitektur modern diterapkan pada rumah tinggal tersebut. Studi ini menggunakan kombinasi metoda deskriptif kualitatif, historis, dan grafis sekaligus. Dari hasil analisis, diperoleh hasil bahwa beragam langgam arsitektur modern yang popular pada saat itu dapat dijumpai pada desain rumah tinggalnya.
\end{abstract}

Kata kunci: Tan Tjwan Bie, Cosman Citroen, Gerard Pieter Adolfs, arsitektur modern, arsitektur kolonial Belanda

\section{ABSTRACT}

In the social stratification created by the Dutch colonial government, Chinese community in the Netherlands Indies occupied the second place, after Europeans. They live scattered in various cities, one of them is Surabaya. In this city they also settled in the second place after the indigenes in terms of numbers. Tan Tjwan Bie, one of them, was known as the founder of Kebon Agung sugar factory in Malang. With the financial ability, he was able to hire Cosman Citroen, one of the leading architects in the Netherlands Indies, and Gerard Pieter Adolfs, an internationally reputed painter, to design his mansion, as well as a prominent contractor of Nedam appointed to build it until its completion in 1928. At that time, modern architecture was growing rapidly. As a collaborative work of various prominent parties with different backgrounds, this building is worthy of being examined in its architectural style. This paper aims to identify the extent of the influence of modern architecture on this mansion. This study used a combination method of historical, qualitative descriptive, and graphics methods. The result shows that various styles of modern architecture which were popular at the time could be found in the design of his mansion.

Keywords: Tan Tjwan Bie, Cosman Citroen, Gerard Pieter Adolfs, modern architecture, Dutch colonial architecture 


\section{Pendahuluan}

Komunitas Tionghoa menempati posisi kedua, setelah pribumi, dalam komposisi penduduk di Surabaya selama kurun waktu 1921-1930 (Statistiek, 1931). Merujuk pada kebijakan pemerintah kolonial Belanda tentang klas etnik yang ditetapkan di dalam Regeringsreglement (Peraturan Pemerintah) tahun 1854 (Noordjanah, 2004), mereka berada di klas kedua, setelah orang-orang Eropa, sedangkan penduduk pribumi menempati posisi ketiga atau terendah. Mereka bertempat tinggal terpusat di daerah Pecinan yang biasanya berada di benedenstad (kota bawah) yang mencakup area Kapasan, Kembang Jepun, Panggung, Songoyudan, Bibis, dan Bongkaran. Kondisi ini merupakan penerapan apa yang disebut sebagai Wijkenstelsel (Sistem Distrik), yaitu suatu aturan yang menetapkan wilayah permukiman Tionghoa (Pecinan) atau permukiman penduduk non pribumi lain yang besar (dalam hal jumlah) di berbagai kota-kota besar di Hindia Belanda. Setelah terjadinya pembantaian orang-orang Tionghoa di Batavia pada tahun 1740, mereka dilarang bertempat tinggal di sembarang tempat (Anonymous, 2014). Pemerintah bermaksud mencegah interaksi di antara orang pribumi dengan kelompok etnis Tionghoa dengan menerapkan passenstelsel (sistem paspor) dan wijkenstelsel untuk memusatkan kegiatan ekonomi mereka di zona urban tertentu. Dengan sistem paspor, orang Tionghoa yang akan melakukan perjalanan ke luar dari daerah tempat tinggalnya harus membawa kartu pass jalan.

Saat aktivitas ekonomi beralih ke sektor industri, komunitas Tionghoa merupakan kelompok masyarakat yang paling siap dengan spesialisasinya dalam bidang makanan dan minuman, peralatan rumah tangga, bahan bangunan, batik, rokok kretek, dan jasa angkutan (Anonymous, 2014). Karena sebagian besar dari mereka dikenal sebagai pedagang pada akhirnya Pecinan menjadi kawasan bisnis tersibuk di kota. Beberapa perusahaan dagang mereka berkembang cepat sehingga mereka tidak hanya berdagang komoditi tetapi juga memproduksinya. Hal ini tidak hanya terjadi di Surabaya tetapi juga di kota-kota lain. Setelah pemerintah kolonial Belanda memberlakukan dua undangundang, yaitu UU Gula (Suiker Wet) dan UU Agraria (Agrarische Wet) di tahun 1870, tidak sedikit di antara mereka yang masuk dalam perdagangan gula dan mendirikan pabrik gula sendiri. Salah satu di antara mereka adalah Tan Tjwan Bie.

Tan Tjwan Bie dapat digolongkan sebagai 'raja gula' di Jawa Timur pada jamannya karena dialah pendiri Pabrik Gula Kebon Agung di Malang pada tahun 1905 (Anonymous, 2019). Sayangnya, informasi lebih lanjut dan lengkap tentang sosok Tan Tjwan Bie, baik dari sisi pribadi, keluarga, latar belakang pendidikan, pemikiran, pengalaman, dan pandangan kulturalnya, tidak dapat diperoleh. Satu-satunya dokumen yang dapat ditemukan adalah sebuah foto Tan Tjwan Bie (Gambar 1). Tidak seperti orang Tionghoa yang pada umumnya berbusana seperti leluhurnya, Tan Tjwan Bie berpenampilan modern

seperti orang Eropa, yaitu memakai kemeja dan celana panjang serta dilengkapi dengan mantel (coat) dan topi. 


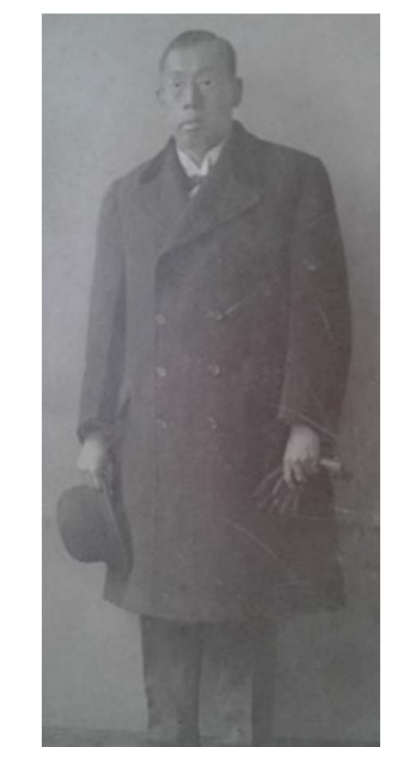

Gambar 1. Tan Tjwan Bie

(Sumber: Haryono, 2016)

Sebelum Tan Tjwan Bie membangun rumahnya di Jalan Kayun 42 (Hekkelman, 1923), ia menetap di Malang saat mendirikan pabriknya. Rumah di jalan tersebut merupakan proyek yang menarik karena merupakan hasil kerjasama antara pemilik yang merupakan orang kaya dengan arsitek terkenal, pelukis ternama, dan kontraktor terkemuka. Ia mampu menyediakan dana besar untuk desain yang kontemporer dan mewah dengan material bangunan terbaik.

Arsitek yang merancang rumah ini, yaitu Cosman Citroen (1881-1935), merupakan sosok arsitek yang sudah dikenal di Surabaya dan cakap dalam berbagai hal (versatile) desain dengan beragam proyek-proyeknya, mulai dari perabot hingga tata ruang kota, dan dari desain arsitektural hingga konstruksi sipil (Santoso, 2010). Di proyek ini, ia bisa merancang rumah tersebut hampir tanpa kendala keuangan dan dapat diselesaikan pada tahun 1928 (Zeeuw, 2001).

Seorang pelukis ternama yang terlibat, yaitu Gerard Pieter Adolfs (1898-1968), awalnya berlatar belakang arsitektur tapi akhirnya pindah haluan dan berkarya sebagai seorang seniman lukis. Ia merupakan pelukis yang telah memamerkan karya-karyanya di tingkat internasional, baik di Eropa, Amerika, dan tentu saja di Asia sepanjang kariernya sejak tahun 1922 hingga tahun 1967 (Borntraeger-Stoll, n.d).

Dan pihak terakhir, yaitu kontraktor bangunan Nederlandse Aannemingsmaatschappij (Nedam) mampu mewujudkan desain yang dibuat oleh Citroen dan Adolfs menjadi salah satu karya terbaiknya dan diselesaikan pembangunannya pada tahun 1928. Nedam merupakan salah satu kontraktor bangunan ternama dan karyakaryanya tersebar di berbagai tempat di Hindia Belanda (Anonymous, 2015).

Pada masa itu, yaitu tahun 1920-an, arsitektur modern sedang berkembang pesat di Hindia Belanda, termasuk Surabaya sebagai kota terbesar kedua di koloni Belanda ini. Beragam langgam arsitektural yang berkembang di luar Hindia Belanda dicoba diterapkan pada bangunan-bangunan yang dirancang oleh berbagai arsitek di koloni ini. Tentu saja, ragam langgam arsitektural dari negeri Belanda akan menjadi sangat dominan.

Sebagai karya arsitektural hasil kolaborasi dari berbagai pihak yang menonjol dan berbeda latar belakangnya, rumah ini menjadi sangat layak dan menarik untuk diteliti. Dari paparan sebelumnya, muncul pertanyaan langgam arsitektural apakah yang dipakai pada desain rumah ini? Bagian-bagian arsitektural mana saja yang mendapat pengaruh 
langgam-langgam tersebut? Adakah tokoh-tokoh tertentu yang mempengaruhi desain yang dibuat oleh Citroen dan Adolfs?

\section{Bahan dan Metode}

Studi ini dilaksanakan dengan menggunakan perpaduan antara metoda kesejarahan, grafis, dan deskriptif kualitatif. Metoda kesejarahan diterapkan terkait dengan sumber data. Data kesejarahan didapat dari publikasi lama dan arsip. Publikasi lama yang dipakai berupa laporan statistik, buku alamat, dan periodikal lembaga atau institusi terkait. Dokumen-dokumen ini diperoleh dari koleksi Dinas Perpustakaan dan Kearsipan Pemerintah Kota di Surabaya, Koninklijk Instituut voor Taal-, Land- en Volkenkunde (KITLV) atau Institut Kerajaan untuk Studi Asia Tenggara dan Karibia di Kota Leiden, Belanda, koleksi pribadi perseorangan, dan beberapa situs dalam jaringan internet.

Data grafis atau image berupa cetak biru atau blueprint juga diperoleh dari koleksi Dinas Perpustakaan dan Kearsipan Pemerintah Kota Surabaya. Foto lama rumah Tan Tjwan Bie didapat dari buku sejarah Kota Surabaya yang ditulis oleh Broeshart (1994). Sedangkan gambar bangunan-bangunan sejaman, baik karya Citroen atau pun karya arsitek-arsitek lain diperoleh dari buku Akihary (2006) dan Diessen dan Voskuil (1998), serta beberapa situs dalam jaringan internet. Foto-foto rumah kondisi saat ini diperoleh dari survei lapangan. Kesemua data grafis tersebut dibandingkan desainnya untuk dicari kaitannya.

Metoda deskriptif kualitatif yang didasarkan pada pendekatan sinkronik diterapkan untuk menjawab pertanyaan penelitian yang muncul di bagian pendahuluan. Pendekatan sinkronik merupakan pendekatan dengan melihat beragam aspek yang terjadi di luar obyek penelitian dalam kurun waktu yang (hampir) bersamaan, khususnya dalam bidang arsitektur. Atau dengan kata lain, pendekatan sinkronik merupakan pendekatan kesejamanan.

Pada obyek kajian, pengamatan ditekankan pada tata massa, tata ruang, dan detaildetail arsitekturnya. Pilihan pada ketiga variabel ini didasarkan pada anggapan bahwa langgam arsitektur suatu desain bangunan dapat dikenali dari ketiga hal tersebut.

\section{Hasil dan Diskusi}

\subsection{Tata Massa}

Tapak rumah Tan Tjwan Bie berbentuk persegi panjang, menghadap ke arah timur, yaitu ke Jalan Kayun. Di seberang tapak terdapat Kali Mas. Desain rumah terdiri dari tiga massa, yaitu satu massa utama berupa rumah induk dan dua massa penunjang berupa pavilyun di sebelah kanan dan kirinya, sehingga tatanan massanya membentuk komposisi yang simetris (Gambar 2 dan Gambar 3). Tata massa yang simetris merupakan salah satu karakteristik arsitektur Tionghoa pada umumnya. Terdapat koridor beratap sebagai penghubung ketiga blok massa tersebut. Bagian ini juga bertindak sebagai pembatas antara halaman depan dengan halaman belakang sehingga pemisahan antara ruang publik di depan dengan ruang privat di belakang menjadi sangat jelas. 


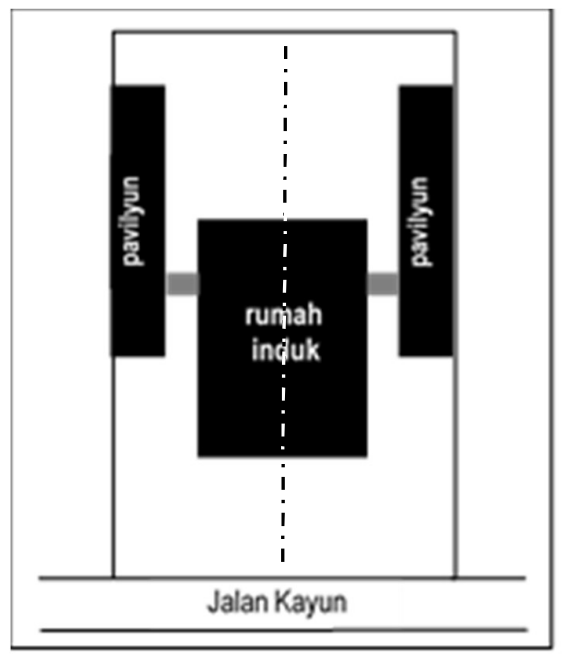

Gambar 2. Denah Blok

(Sumber: Dokumentasi pribadi, 2010)

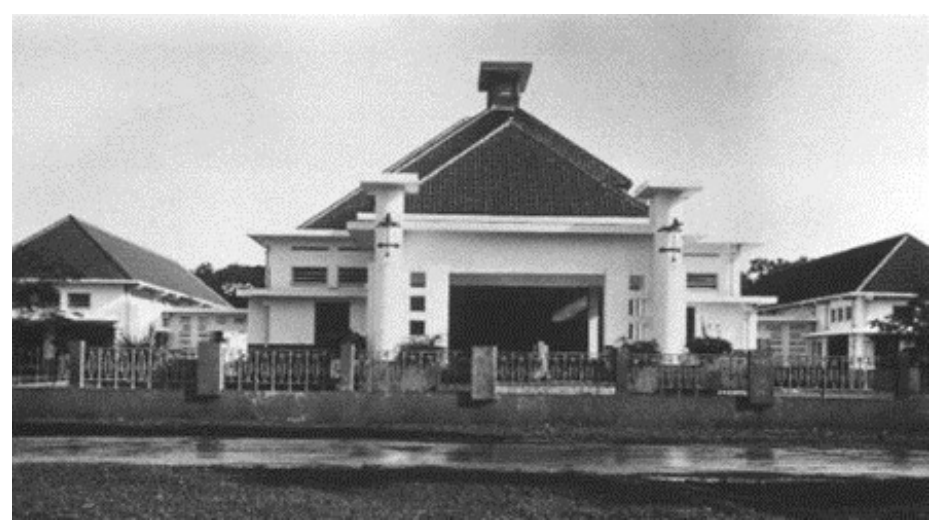

Gambar 3. Tampak Depan sekitar Tahun 1935

(Sumber: Broeshart et al, 1994)

Rumah induk beratap limasan yang bubungannya sejajar dengan jalan. Untuk menaungi serambi depan dan ruang lain di bagian depan, arsitek Citroen mendesain atap limasan yang lebih kecil menempel pada atap limasan utama sehingga terdapat tiga atap limasan pada rumah induk. Bubungan kedua atap limasan kecil tegak lurus terhadap atap limasan utama. Agar lebih menarik, Citroen menempatkan mahkota atap pada atap limasan utama (Gambar 4), yang terbuat dari kayu yang berjalusi di keempat sisinya yang berfungsi untuk mengeluarkan udara panas dari ruang bawah atap. Citroen juga merancang atap beton datar untuk menaungi hall masuk di bagian depan yang diapit oleh dua menara lengkung kecil di kedua sudutnya. 


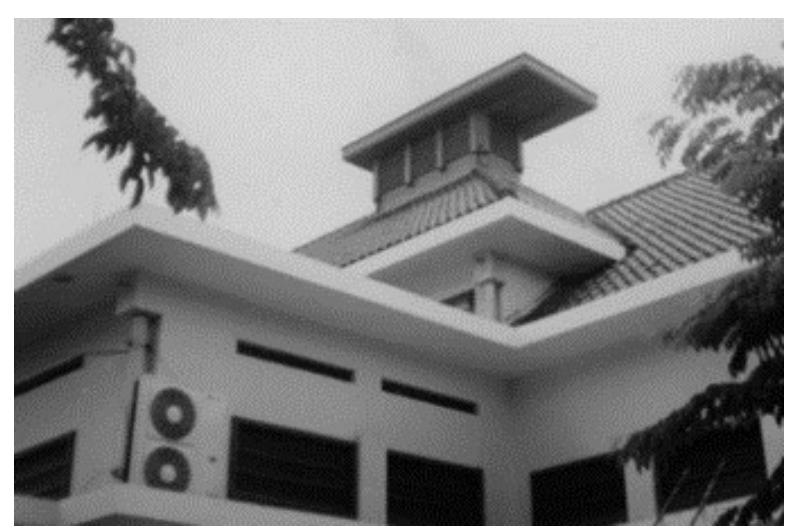

Gambar 4. Mahkota di Atap Rumah Induk

(Sumber: Dokumentasi pribadi, 2010)

\subsection{Tata Ruang}

Denah rumah induk tersusun dari empat 'lapis' dengan tata ruang yang simetris (Gambar 5). Lapis pertama di sisi depan merupakan serambi lebar dengan langit-langit tinggi berbahan kayu jati, diapit oleh teras terbuka di kedua sisinya. Lapis kedua terdiri dari ruang tamu dan ruang tidur. Ruang makan, dapur, dan ruang-ruang lain berada di lapis ketiga. Lapis keempat atau terdalam berfungsi sebagai serambi belakang, juga berlangitlangit kayu jati yang cukup tinggi lengkap dengan teras kecil. Serambi ini terhubung dengan kedua pavilyun melalui koridor.

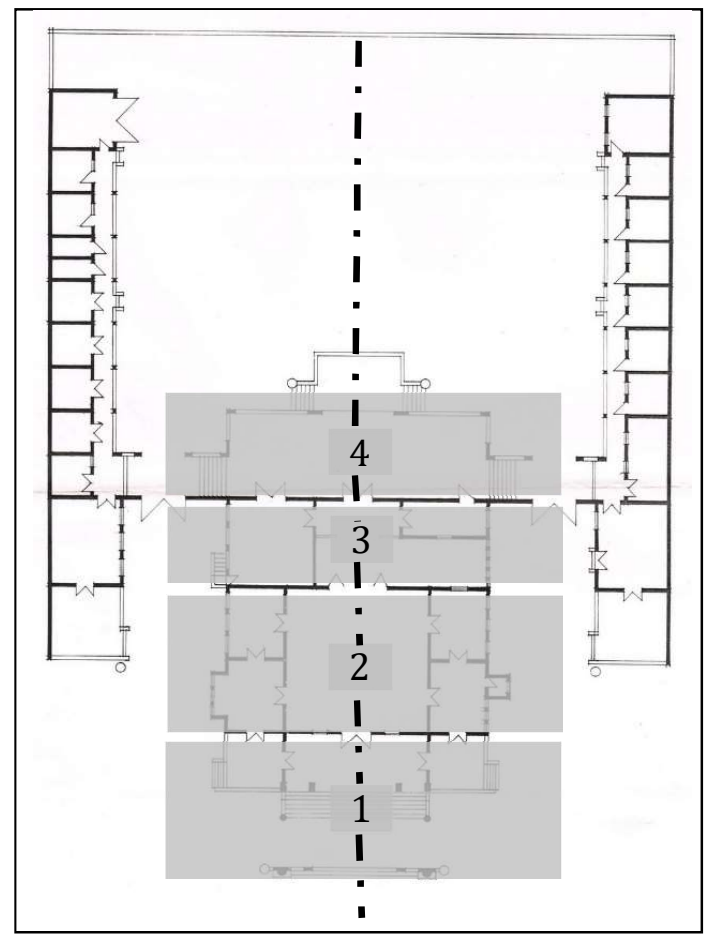

Gambar 5. Denah

(Sumber: Dokumentasi pribadi, 2010)

Ruang-ruang di bagian pavilyun kiri dan kanan yang beratap limasan disusun hampir identik. Semua ruang disusun berjajar ke belakang. Dua ruang besar mengapit di 
bagian awal dan akhir pavilyun ini. Citroen merancang teras yang lebar, di depan deretan ruang tersebut, yang berfungsi sebagai ruang transisi dan pada saat yang sama bertindak sebagai penahan (buffer) suhu yang tinggi di luar ruang.

Penerapan arsitektur tropis dapat ditemukan pada penggunaan koridor panjang di tepi ruang dalam dan teritisan atap yang lebar (Gambar 6). Kedua elemen arsitektural tersebut mampu meredam suhu di dalam ruang akibat pengaruh suhu tinggi di luar ruang.

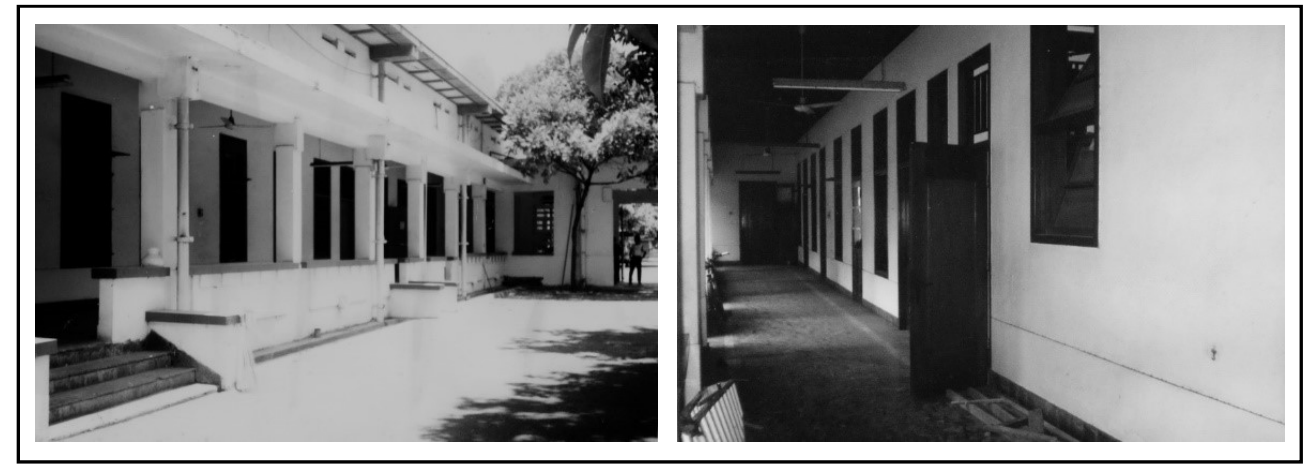

Gambar 6: Galeri

(Sumber: Dokumentasi pribadi, 2010)

\subsection{Detail Arsitektural}

Selain ragam hias di atap, Citroen merancang lampu gantung pada menara lengkung penyangga kanopi beton di bagian depan (Gambar 7 kiri) dan ornamen besi pada pagar tangga (Gambar 7 kanan). Juga terdapat pot bunga berbentuk hampir setengah bola berukuran cukup besar di teras depan rumah induk. Ada kemiripan desain antara pot bunga karya Citroen ini dengan pot bunga karya Frank Lloyd Wright, tokoh arsitektur modern internasional (Gambar 8). Wright sering menggunakan elemen ini pada karyakaryanya, seperti rumah William H. Winslow (River Forest, Illinois, 1893), rumah Nathan G. Moore (Oak Park, Chicago, Illinois, 1895 dan didirikan kembali pada tahun 1923), rumah Ward W. Willit (Highland Park, Illinois, 1901), rumah Arthur Heurtley (Oak Park, Chicago, Illinois, 1902), dan rumah Susan Lawrence Dana (East Laurence Avenue, Springfield, Illinois, 1903).

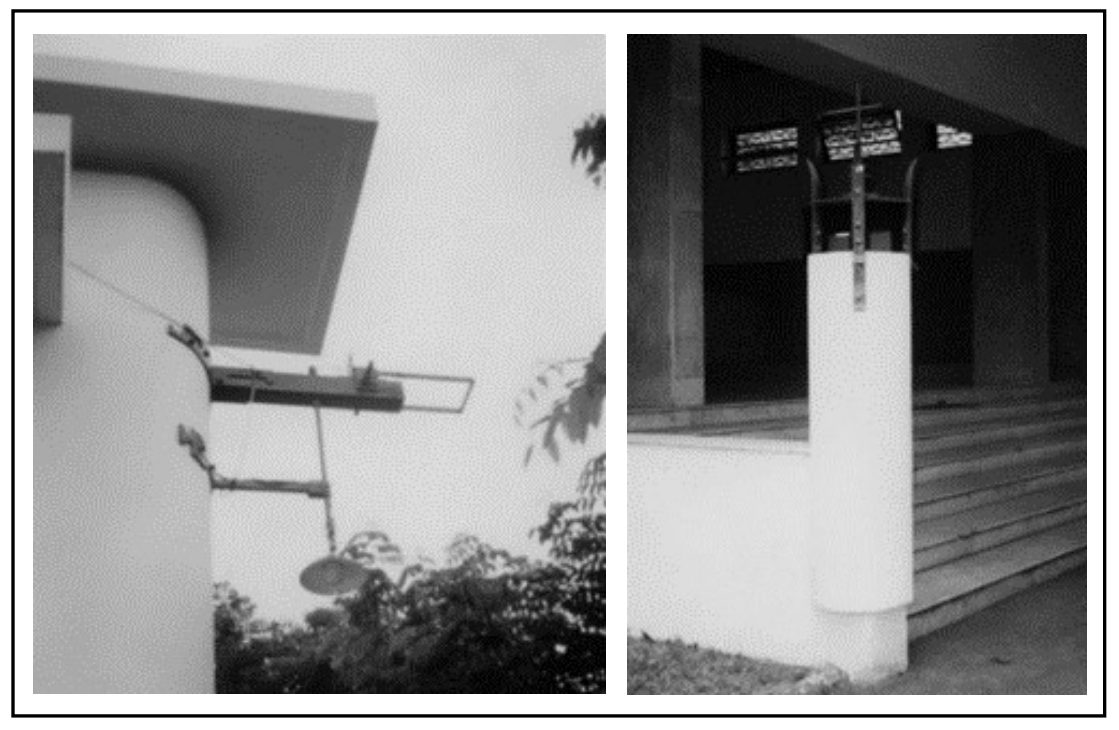

Gambar 7. Lampu Gantung dan Ornamen Besi (Sumber: Dokumentasi pribadi, 2010) 


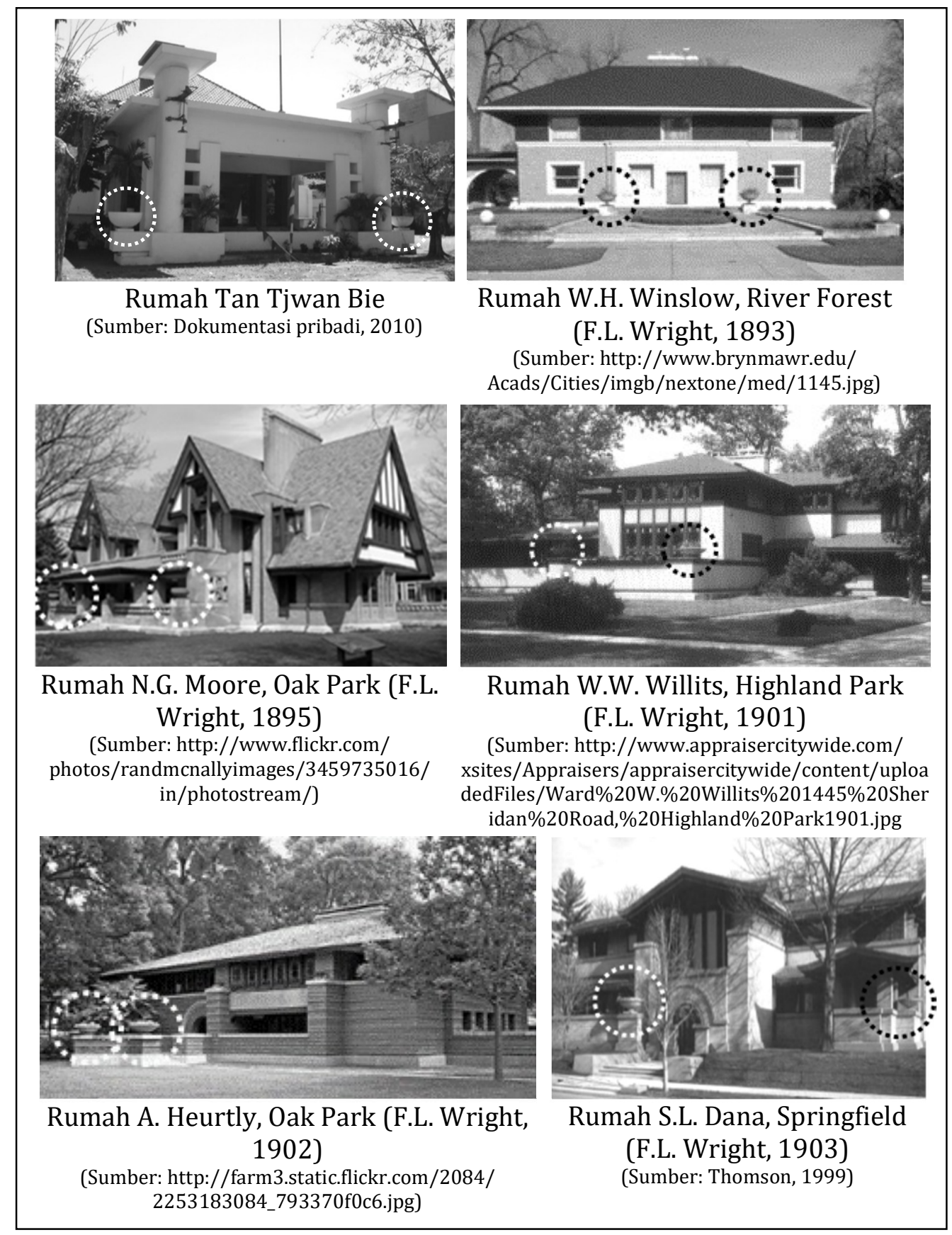

Gambar 8. Komparasi Pot Bunga

Ruang dalam rumah induk didominasi panel kayu jati berwarna natural untuk langit-langit dan dinding bagian bawah. Bahan yang sama dipergunakan juga untuk pintu, jendela, dan permukaan kolom. Kepala kolom dirancang dengan langgam Art Deco. Desainnya serupa dengan desain kapital kolom karya Frank Lloyd Wright di Gereja Unity, Oak Park, Chicago, Illinois tahun 1906 (Gambar 9). Kayu jati solid dipergunakan sebagai dua pasang kolom non-struktural yang mengapit pintu (Gambar 10). Kolom-kolom ini berkapital ukiran dengan motif flora. 


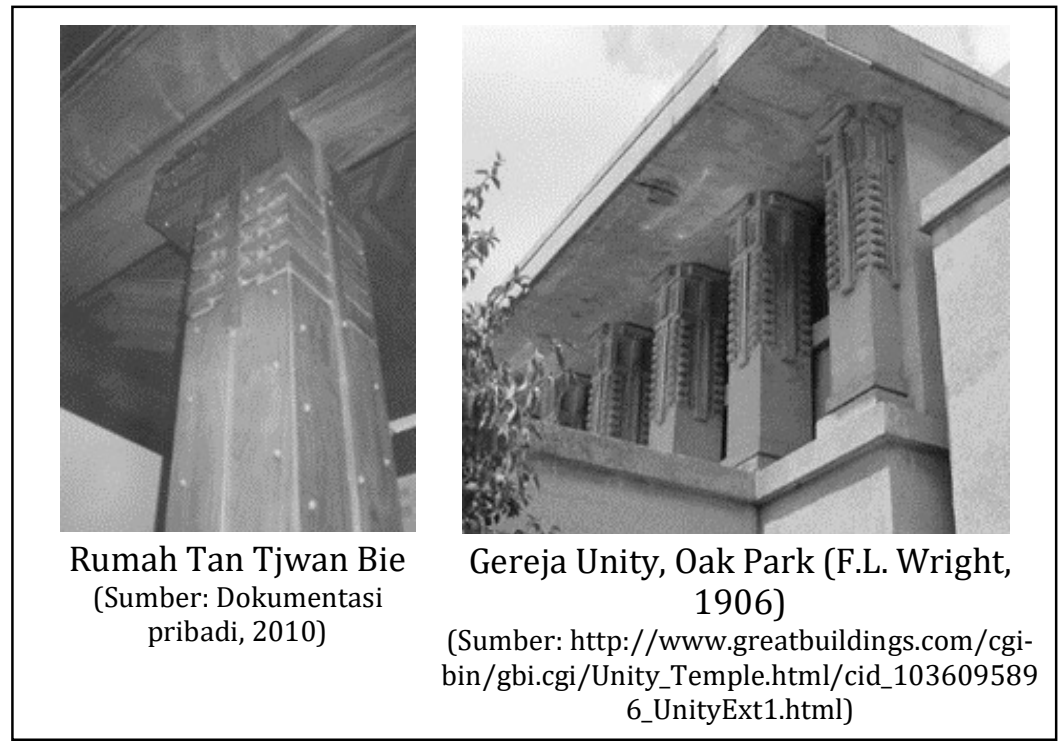

Gambar 9. Komparasi Kapital Kolom

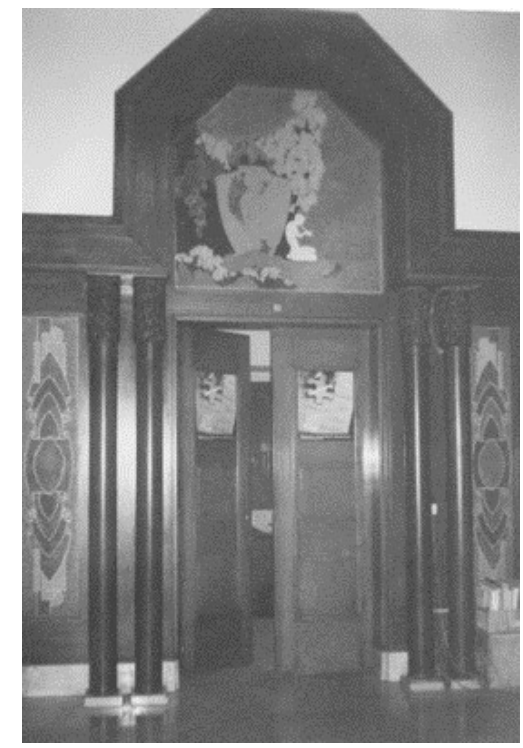

Gambar 10. Kolom

(Sumber: Dokumentasi pribadi, 2010)

Pelukis Adolfs merancang mural di ruang tamu berlanggam Art Deco (Gambar 11). Ia melukis pemandangan dengan figur manusia dan motif flora, binatang (burung dan kupu-kupu), dan elemen-elemen arsitektural. Contoh menarik dari obyek terakhir ini adalah outline/siluet tiang lampu yang desainnya sama dengan desain tiang lampu Jembatan Wonokromo yang dirancang Citroen pada bulan Maret 1928, tahun yang sama dengan perancangan rumah Tan Tjwan Bie (Gambar 12). Temuan ini diperoleh dari komparasi antara foto mural dengan cetak biru Jembatan Wonokromo. Contoh lain adalah bagian bangunan yang hampir mirip dengan bagian gedung "Internatio" di Willemsplein, kawasan niaga di kota bawah (Gambar 13). Gedung tersebut dirancang pada tahun 19271928 oleh F.J.L. Ghijsels dengan sejawatnya di biro arsitektur Ingenieurs- en Architectenbureau (AIA) untuk Internationale Handels- en Credietvereeniging "Rotterdam", disingkat Internatio, dibangun tahun 1929-1931, dan diresmikan pada tanggal 1 Agustus 1931. 


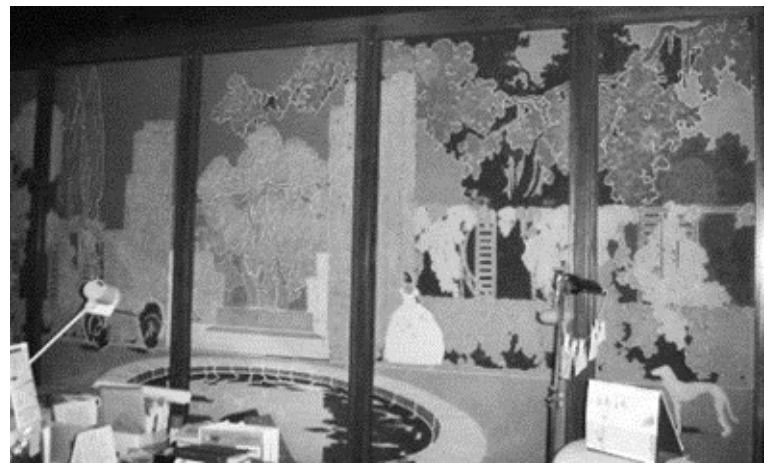

Gambar 11. Mural Adolfs

(Sumber: Dokumentasi pribadi, 2010)

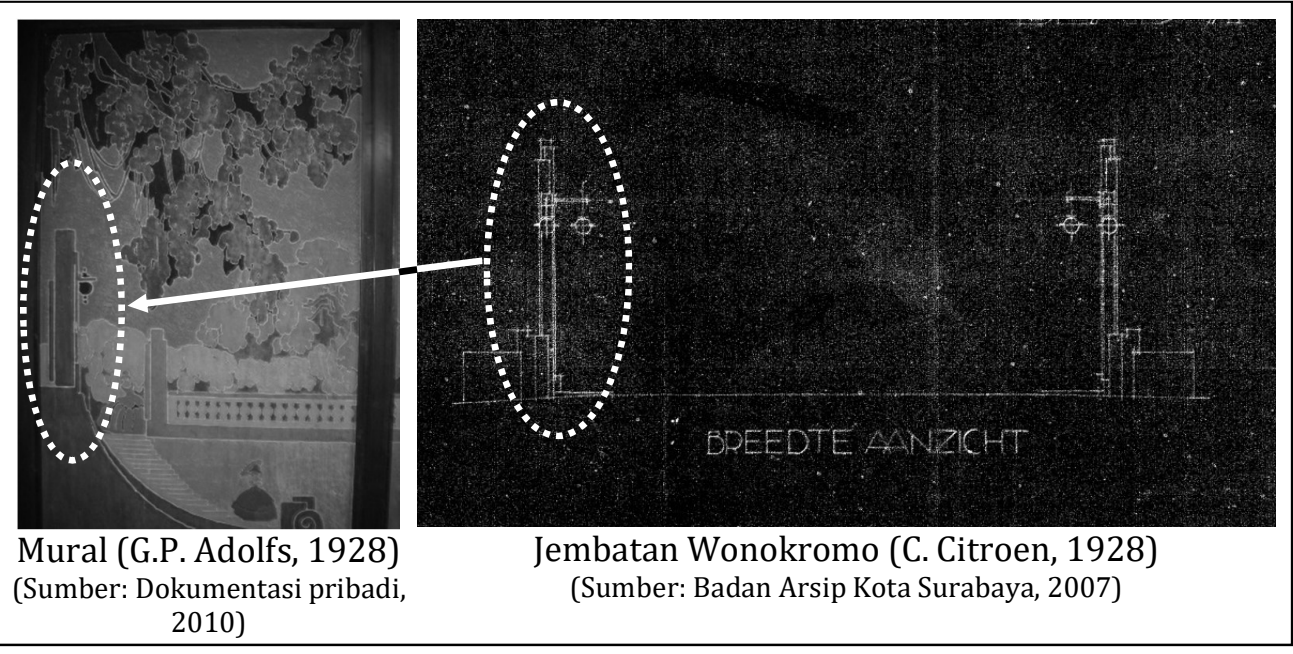

Gambar 12: Lampu Jembatan Wonokromo di Mural Adolfs

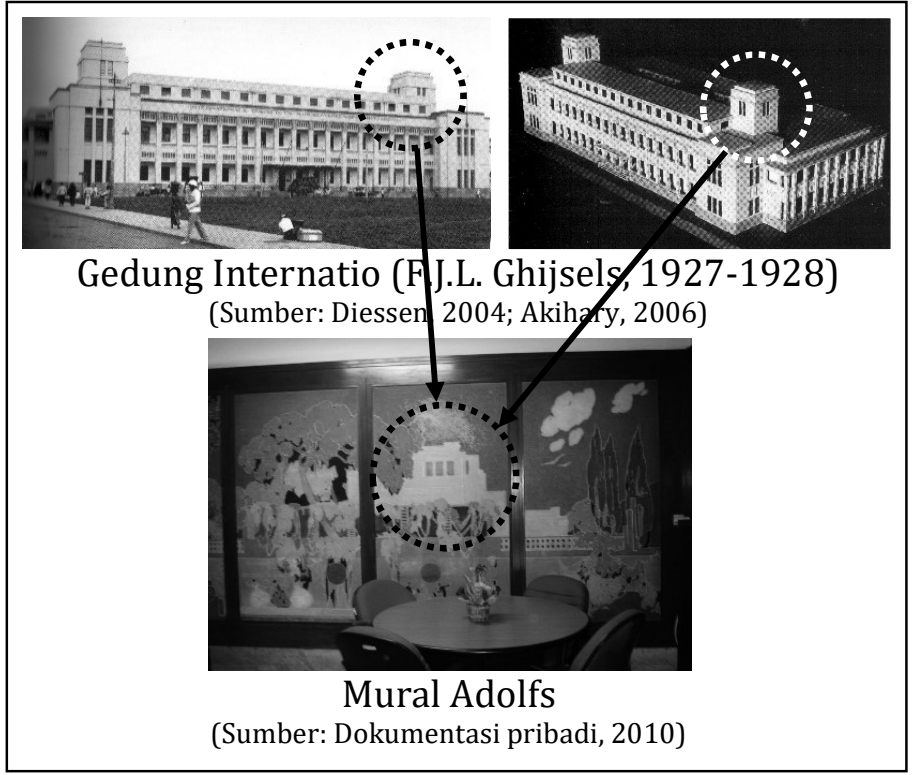

Gambar 13: 'Gedung Internatio’ dalam Mural Adolfs 
Citroen juga memperhatikan desain lantai dengan cara mengkombinasikan warnawarna terang dan gelap. Warna terang dipakai untuk membingkai warna gelap. Ia memperkuat ubin pembingkai dengan meletakkan dua deret bentuk-bentuk persegi di sepanjang kedua sisi ubin sehingga membentuk suatu batas di dalam batas. Untuk menghindari kemonotonan, dia menambahkan lukisan burung bergaya Art Deco (Gambar 14).

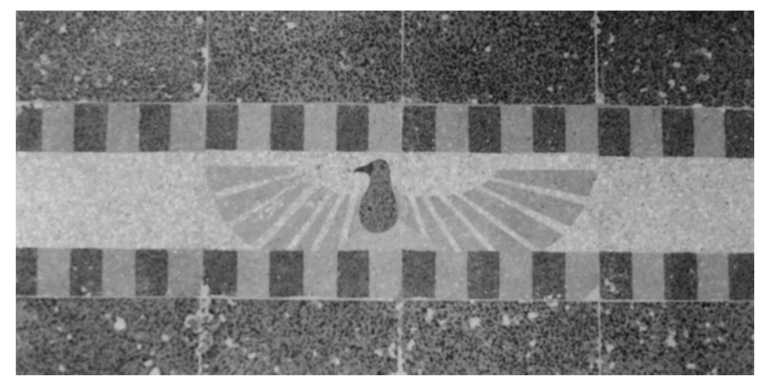

Gambar 14. Ubin

(Sumber: Dokumentasi pribadi, 2010)

Pola geometris De Stijl, seperti pola desain pada karya-karya Theo van Doesburg dan Piet Mondrian, dapat ditemukan di kaca patri pintu, jendela atas, dan terali besi jendela (Gambar 15). Keduanya dikenal sebagai tokoh De Stijl, suatu langgam seni dan arsitektur yang berkembang di Belanda sekitar tahun 1917-1931.

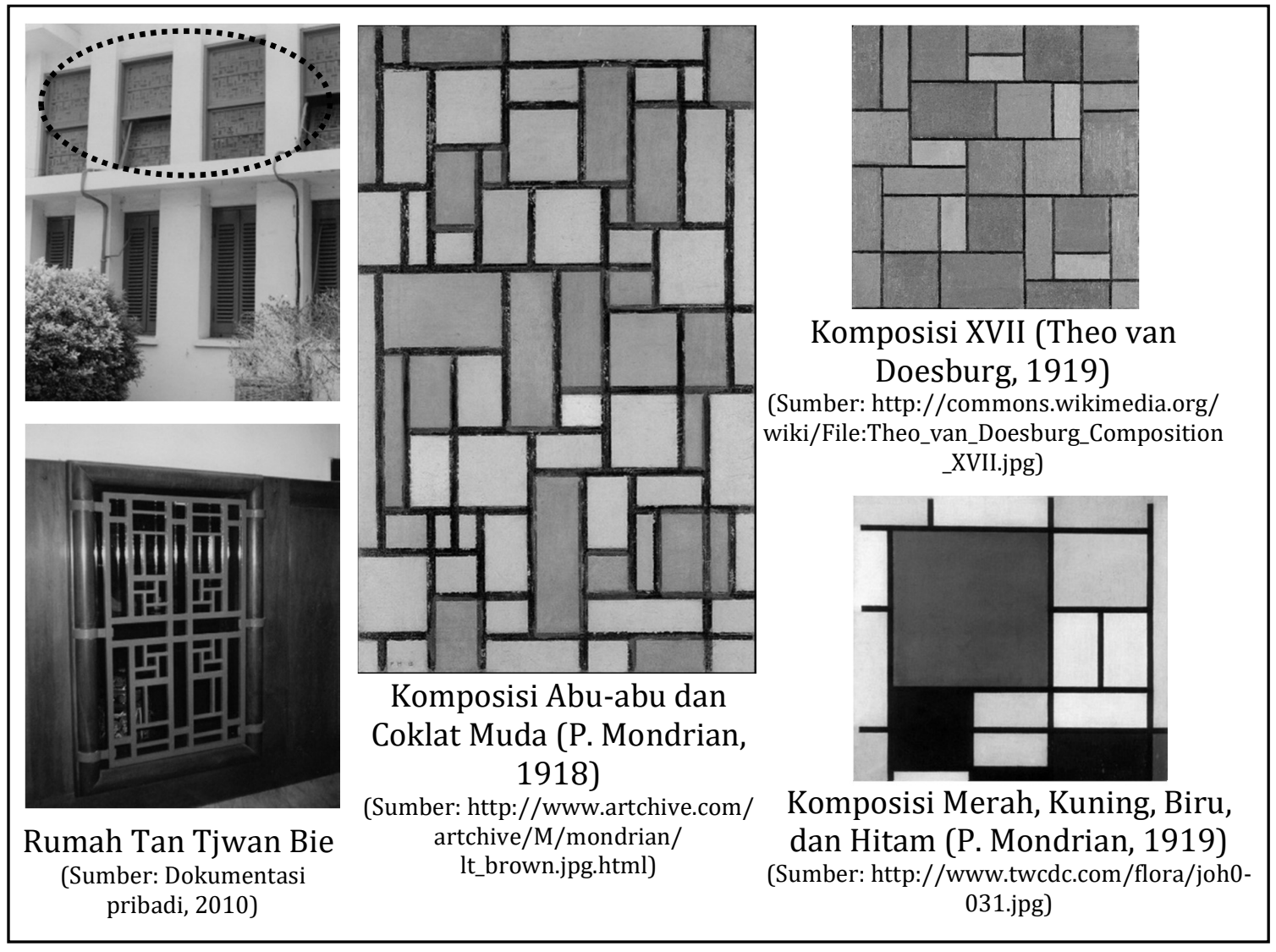

Gambar 15. Komparasi Pola Geometri 


\section{Simpulan}

Rumah tinggal Tan Tjwan Bie di Jalan Kayun 42 Surabaya merupakan karya arsitek C. Citroen dan pelukis G.P. Adolfs yang lebih menerapkan konsep arsitektur modern hibrida yang menarik dibandingkan dengan arsitektur Tionghoa. Konsep arsitektur modern sepertinya dipilih sesuai kepribadian pemiliknya yang gemar mengenakan pakaian langgam barat, tidak seperti orang Tionghoa pada umumnya di jamannya, setidaknya terlihat dari satu-satunya foto yang dapat ditemukan.

Tata massa bangunan mengikuti prinsip simetris yang biasa ditemui di arsitektur Tionghoa. Tata ruang rumah induk dirancang dengan lebih memperhatikan aspek fungsional yang mencerminkan arsitektur modern, meskipun kesimetrisan tata ruang rumah tinggal Tionghoa masih dapat ditemukan di sini. Langgam Art Deco diterapkan pada eksterior dan interiornya. Bagian fasade diperkaya dengan langgam De Stijl dan Amsterdam School. Citroen juga tidak melupakan prinsip-prinsip perancangan bangunan di daerah tropis. Pengaruh tokoh-tokoh arsitektur modern dunia, khususnya Frank Lloyd Wright, Theo van Doesburg, dan Piet Mondrian, juga dapat ditemukan di rumah ini. Jadi, meski bangunan ini dibangun dan dimiliki oleh seorang Tionghoa, desain arsitekturalnya lebih mencerminkan arsitektur modern yang populer pada jamannya dibandingkan dengan arsitektur Tionghoa.

\section{Daftar Pustaka}

Akihary, Huib. (2006). Ir. F.J.L. Ghijsels, Architect in Indonesia (1910-1929), edisi 2. Utrecht: Seram Press.

Anonymous. (2014). Wijkenstelsel. $\quad$ Retrieved from http://id.wikipedia.org/wiki/Wijkenstelsel

(2015). Ballast Nedam. Retrieved from https://en.wikipedia.org/wiki/Ballast_Nedam

(2019). Sejarah PT. Kebon Agung. Retrieved from http://www.ptkebonagung.com/index.php/profil/pt-kebon-agung/sejarah-ptkebon-agung

Borntraeger-Stoll, Eveline. (n.d). Adolfs: Curriculum Vitae. Retrieved from http://www.gerardpieteradolfs.com/curriculum\%20vitae.htm

Broeshart, AC et al. (1994). Soerabaja: Beeld van een Stad. Purmerend: Asia Maior.

Badan Arsip Kota Surabaya. (2007). Wonokromo Brug, cetak biru tahun 1928. Surabaya.

Haryono, Steve. (2016). Tan Tjwan Bie. foto koleksi pribadi.

Hekkelman, G.M. (1923). Algemeen Chineesch Adresboek voor Nederlands-Indië 1923-1924.

Soerabaia: NV. Anetakantoor.

http://commons.wikimedia.org/wiki/File:Theo_van_Doesburg_Composition_XVII.jpg

http://farm3.static.flickr.com/2084/2253183084_793370f0c6.jpg

http://www.appraisercitywide.com/xsites/Appraisers/appraisercitywide/content/uplo

adedFiles/Ward\%20W.\%20Willits\%201445\%20Sheridan\%20Road,\%20Highland\%

20Park1901.jpg

http://www.artchive.com/artchive/M/mondrian/lt_brown.jpg.html

http://www.brynmawr.edu/Acads/Cities/imgb/nextone/med/1145.jpg

http://www.flickr.com/photos/randmcnallyimages/3459735016/in/photostream/

http://www.greatbuildings.com/cgi-

bin/gbi.cgi/Unity_Temple.html/cid_1036095896_UnityExt1.html

http://www.twcdc.com/flora/joh0-031.jpg

Noordjanah, Andjarwati. (2004). Komunitas Tionghoa di Surabaya (1910-1946). Semarang: Mesiass. 
Santoso, Joko Triwinarto. (2010). A Study of Architect Cosman Citroen (1881-1935) and His Works in Surabaya. Disertasi. Leiden: Universiteit Leiden.

Statistiek, Bureau van. (1931). Statistische Berichten der Gemeente Soerabaja, Jaarnummer 1930. Soerabaja: Martinus Nijhoff.

Thomson, Iain. (1999). Frank Lloyd Wright, a Visual Dictionary. San Diego, CA: Thunder Bay Press.

Zeeuw, Wouter de. (2001). Cosman Citroen 1881-1935, naskah terketik. Rotterdam: NAI. 